Swarthmore College

Works

1979

\title{
Food, Politics, And Agricultural Development: Case Studies In The Public Policy Of Rural Modernization
}

\author{
Raymond F. Hopkins \\ Swarthmore College, rhopkin1@swarthmore.edu \\ D. J. Puchala \\ R. B. Talbot
}

Follow this and additional works at: https://works.swarthmore.edu/fac-poli-sci

Part of the Political Science Commons

Let us know how access to these works benefits you

\section{Recommended Citation}

Raymond F. Hopkins, D. J. Puchala, and R. B. Talbot. (1979). "Food, Politics, And Agricultural Development: Case Studies In The Public Policy Of Rural Modernization". Food, Politics, And Agricultural Development: Case Studies In The Public Policy Of Rural Modernization.

https://works.swarthmore.edu/fac-poli-sci/124

This work is brought to you for free by Swarthmore College Libraries' Works. It has been accepted for inclusion in Political Science Faculty Works by an authorized administrator of Works. For more information, please contact myworks@swarthmore.edu. 


\title{
1 \\ The Politics of Agricultural Modernization
}

\author{
Donald J. Puchala \\ Raymond F. Hopkins
}

The history of every modern country includes an account of how agricultural change occurred. The forces that stimulated rural populations to adopt new farming techniques or to abandon the land for urban society have also stirred major political struggles. In each country the struggle for advantage in the countryside presents unique factors; but in each this struggle-over control of land or the income from its product-has had important consequences for the values, stability, and form of politics of the country. Today, the politics of agriculture in the less-developed countries turn on issues of access to land and control of credit, markets, or other economic relationships.

This volume brings together a group of essays that review salient aspects of agricultural change in particular countries. Even though the essays vary in tone, emphasis, and historical or geographical scope, all address similar questions: What role has government generally, and particular government politics specifically, played in the success or failure of agricultural modernization? What political forces has the agricultural sector unleashed, and under what circumstances? Overall, how has the chosen path of agricultural modernization in each case reflected colonial or national politics; and how, in turn, has this affected national politics?

Our fundamental purpose here is to provide case studies of agricultural modernization that emphasize the political aspects and ingredients of development. In doing this we seek to complement the literature of agricultural economics as applied to rural development. Theoretical and technical writings on agricultural modernization are voluminous; the better known recent works are sound, sophisticated, enlightening, and basic to our understanding of development. ${ }^{1}$ Nonetheless, many of those who approach problems of rural development from agronomic and economic perspectives pay scant attention to politics and government and their roles in agriculture. Such 
underemphasis frequently renders analysis incomplete, since public policies toward agriculture influence prices, investment, planting decisions, marketing strategies, land tenure patterns, crop mixes, imports and exports, and rural incomes in every country of the world. Understanding the origins, contents, and impacts of such policies, then, must be fundamental to understanding agricultural development. Even more important, analyses of development that omit the influence of political factors can become theoretical exercises offering little guidance in practical problem solving. For example, development proposals that call for utilizing market forces and matching supply to demand via prices utilize impeccable economic logic. But such prescriptions border on fantasy where government policies regulate commodity and food prices to serve ends other than agricultural development, where they encourage uneconomic factor mixes for political reasons, or where they ration capital for industrialization and thereby inhibit rural investment. Similarly, agronomic prescriptions that anticipate higher yields from better seeds, more fertilizer, and adequately proportioned water are obviously sound. Yet they become practicable only under conditions where information inputs and capital are accessible to rural populations who have been appropriately educated and motivated to innovate. Whether such conditions exist is largely a function of government policy and administrative capacity, and these, in turn, result from political considerations that often have little to do with agriculture as such.

\section{The Meaning of Rural Modernization}

Rural modernization is a complex phenomenon. Although its modes have varied considerably throughout history, and presently vary from region to region, certain general outcomes signal its occurrence. First, agricultural production and productivity increase substantially as modernization proceeds. Enhanced productivity tends to be especially marked with regard to labor and land, and these increases are most frequently the results of changing technology, the second general feature of agricultural modernization. Even though the extent and impacts of technological change differ from country to country, sustained development eventually requires technological change in all cases.

More broadly conceived, rural modernization is an aspect of the structural transformation of economies, a step in the progression that has led countries and peoples from traditional feudal agrarianism to modern urban industrialism. ${ }^{2}$ During modernization, labor moves from 
agriculture to industry as heightened productivity and improved marketing and distribution systems make it possible for those few working in the countryside to feed the many working in the cities. Concurrently, the farmers' greater participation in the cash economy combines with escalating demand for their products to produce a heightened rural well-being, an increase in disposable income, and an enhanced demand for both agricultural inputs and consumer goods. Rural demand stimulates urban industry, and reinvested profits promote further industrial growth, thus creating new urban employment, new demands for food, and further incentives to agriculture. Of course it is a simplification to believe that national economic development and industrialization result solely or even primarily from the rising interdependence of rural and urban demand. But this is not the point. Rather, what is important here is that structural transformation, as reflected in shifting linkages between sectors, is both a result and an index of rural modernization.

Many features of rural modernization are readily observable in the statistical series and quantitative records of countries. Table 1.1, for example, highlights the rural modernization of several countries in terms of production, productivity, input technology, and structural. transformation. Equally relevant and revealing would be figures showing that, typically, during or after agricultural modernization rural wage rates move in tandem with urban ones, rural unemployment and underemployment diminish (partly through migration), rural literacy and education levels rise notably, rural savings and capital increase, and living standards markedly improve, at least for the "successful" farmers. Also, while some of the rural populace are gaining these advantages, others are losing out-squeezed off the bud or impoverished as new technologies and government policies disadvantage them.

There are other aspects of rural modernization that are less quantifiable, but certainly important. For one thing, "successful" peasants typically become farmers during modernization-much more an attitudinal or psychological transformation than a physical one. With this comes a new attentiveness to markets and a new receptivity to innovation, new expectations concerning economic and social mobility within and between generations, new openness to information, a penchant for organization, and, usually, a heightened and more effective political participation. In addition, traditional fatalism in the countryside tends to give way to awareness and confidence in science applied to agriculture. Parochialism diminishes as modern transport 
TABLE 1.1

AGRICULTURAL MODERNIZATION AND STRUCTURAL TRANSFORMATION

United States, Japan, Denmark and France, 1880-1960 $1960=100$

\begin{tabular}{|c|c|c|c|c|c|c|}
\hline Country & 1880 & 1900 & 1910 & $\underline{1930}$ & 1950 & 1960 \\
\hline & & A. & oduc & & & \\
\hline $\begin{array}{l}\text { United States } \\
\text { Japan } \\
\text { Denmark } \\
\text { France }\end{array}$ & $\begin{array}{l}29 \\
28 \\
24 \\
43\end{array}$ & $\begin{array}{l}46 \\
42 \\
31 \\
47\end{array}$ & $\begin{array}{l}48 \\
53 \\
41 \\
53\end{array}$ & $\begin{array}{l}60 \\
69 \\
66 \\
62\end{array}$ & $\begin{array}{l}84 \\
71 \\
76 \\
60\end{array}$ & $\begin{array}{l}100 \\
100 \\
100 \\
100\end{array}$ \\
\hline
\end{tabular}

B. Output Per Male Worker

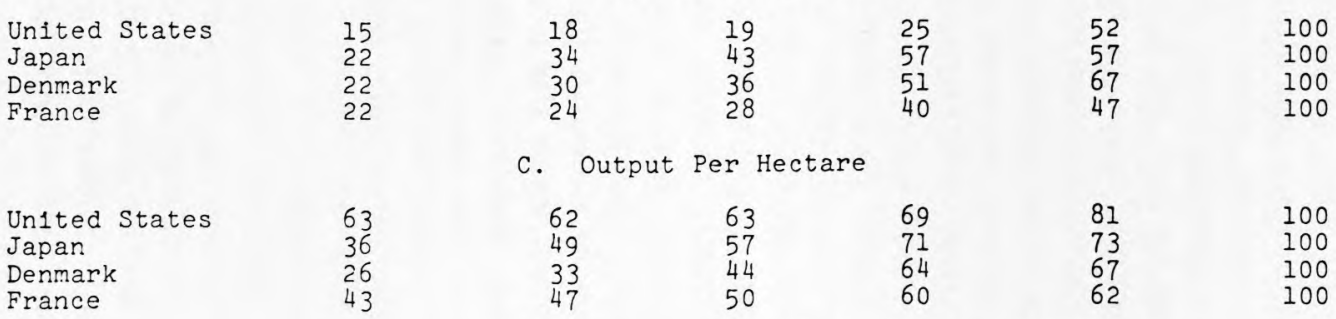

D. Percent Male Workers in Non-Agriculture

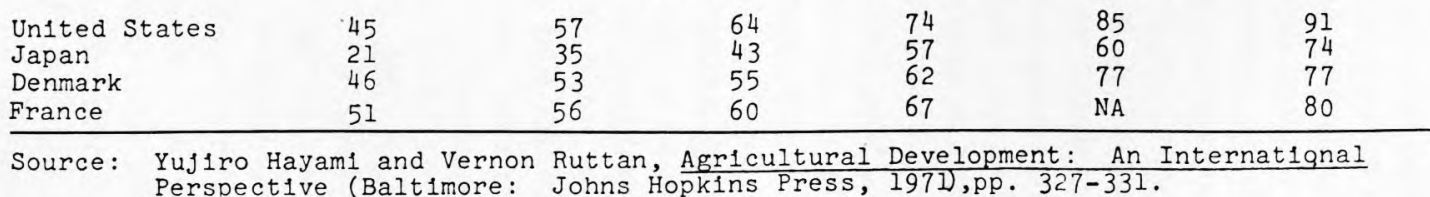


and communications obviate rural isolation: Lifestyles in the countryside become more secular, urbane, and comfortable as material and intellectual poverty recede. ${ }^{3}$ In many aspects the American farmer approximates this ideal, as described by Hadwiger and Talbot in Chapter 2.

What parts do politics and public policy play in the course of such "typical" rural modernization? What roles do public policy and the policy process play in initiating and nurturing the economic, social, and attitudinal transformations involved in evolution from primitive to modern agriculture? Conversely, when, how, and why does public policy, either by commission or omission, hinder, divert, or stifle such transformations? These are the central substantive concerns of our book and the main themes of the collected essays that compose it. Readers will discover, however, that few pat and simple answers emerge to questions about government's role in agricultural modernization, mainly because experiences are so varied and complex. There is no ready formula for agricultural development, no universally reliable policy guideline, no widely prescribable doctrine of innovation and reform, no superior ideology of development. Agriculture has been modernized with a low degree of governmental intervention, as in the United States, and with a high degree, as in Japan. ${ }^{4}$ It has also floundered under a low degree of intervention, as in India during the First and Second Five Year Plans, and under a high degree, as in the Soviet Union in the 1930s. ${ }^{5}$ Similarly, agriculture has been admirably developed under capitalist systems, as in North America and Western Europe, and under socialist ones, as in the People's Republic of China and Cuba. ${ }^{6}$ But modernization has also lagged under both systems, as evidenced by Brazil and Poland. ${ }^{7}$ Land redistribution has furthered development in countries like Taiwan; it was relatively inconsequential in Chile, and it probably set back development in nineteenth century Ireland and in present-day Bolivia. ${ }^{8}$

\section{Analyzing Rural Modernization Policies}

Methodologically, this book is a set of exercises in the comparative analysis of agricultural modernization policies. Those engaged in these exercises begin by assuming that policy outcomes range along a continuum from "success" to "failure," although the criteria for such judgments vary widely. Even the seeming "success" of American agricultural modernization has been challenged recently for its excessive resource depletion, capital-intensiveness, and environmental pollution, as Hadwiger and Talbot note in Chapter 2. Young Kihl finds a success in the declining food self-sufficiency of Korea (see Chapter 6), while a similar decline in Iran seems a failure to Schulz (Chapter 7). Even the 
critique of tractor policy in Pakistan offered by Herring and Kennedy (Chapter 8) indicates debate and ambiguity over the employment and production effects of tractor subsidization, although the effects on income distribution clearly enhance inequalities.

Aside from divergency in evaluating outcomes, we will see from our analyses that outcomes are shaped at different times and places by a combination of factors that we shall term "policy components." In other words, they are shaped by the contents of policies. Analyzing a particular government's policy consists in identifying and accounting for the components of its attitude and actions toward its rural sector either consciously or inadvertently. Evaluating that policy means assessing the appropriateness of the various components (singly or in combination) under prevailing geographic, social, economic, political, and cultural conditions, and studying their effects on agricultural production, rural life, and the political role of agricultural groups.

Policy components assume specific forms and are of great variety and uncertain duration in the modernization process of different countries, yet standard classification is possible. All development policies, for example, are directed toward explicit and/or implicit goals; all prescribe a degree of official intervention into agricultural markets; all embody means or modes of execution; all concern the allocation of resources; all establish or suppress institutions of various kinds. Each of these classifications warrants some elaboration.

\section{The Goals and Priorities of Agricultural Policy}

Generally speaking, agricultural modernization is most readily furthered by agricultural policy when modernization is the goal of such policy. Ironically, this has not always been (nor is it presently) the case. In some countries governmental attitudes toward the countryside and its inhabitants reflect indifference to rural modernization; in other countries policies toward agriculture reflect governmental preoccupations with development in other sectors. For both the Soviet Union and the People's Republic of China priorities in agricultural policy have revolved around ideological aims at creating "new socialist men"; ideological socialization ranked as more important than productivity or production, as Bernstein notes in Chapter 4. India's agricultural policy under the First Five Year Plan set goals of nation-building and integrating above rural development. Iran subordinates development to regime maintenance. Japan's aspirations for Taiwanese agriculture during the colonial period had a good deal more to do with imperial integrity than with rural modernization (see Chapter 5). The point is that governmental goals in agricultural policy vary: some pursuits aid modernization, and others clearly hamper it. 


\section{Acceptability of Market Structures and Processes}

In some countries agricultural development has been encouraged by official reliance on market forces as the means and motors of development-that is, the logic of supply and demand, the efficiency of giving production cues with prices, and the simplicity of adjustment and transformation via open competition. In such cases public policies have mandated government intervention in economic intercourse only to protect property, legalize contracts, standardize weights and measures, or occasionally control abuses and negative effects of the market (see Bates, Chapter 9, on negative externalities). In great contrast, agricultural development in some other countries has been conditioned so widely by public intervention that the effect has been complete suppression of market forces. Under such regimes, market structures are replaced by administrative ones, and market dynamics are superseded by plans, production directives, and rationing schemes. Obviously, the great majority of development regimes fall somewhere between high reliance on market forces, as in early America, and comprehensive regulation, as in the Soviet Union. ${ }^{9}$ The Japanese development experience, for example, has rather elegantly interwoven market forces and administrative controls. ${ }^{10}$ The important analytical point is that the degree and utility of reliance on free markets embodied in rural development policies do not vary by accident among national cases, and the analyst should therefore be attentive to the reasons for and appropriateness of market versus nonmarket emphases under varying conditions.

\section{Means Adopted to Pursue Policy Goals}

Again, the array of ways that governments have gone about pursuing their ends in agriculture, including modernization, is extensive. Some have emphasized fiscal manipulation, as in Brazilian attempts to force heightened productivity by raising land taxes. ${ }^{11}$ Financial means, too, have been used in a variety of ways to channel public funds into forming an infrastructure, subsidizing inputs, prices, and incomes, compensating expropriated landowners, providing credit, furthering research and extension services, and educating farm families. In countries such as Cuba and China where agricultural modernization has been only an aspect of broader programs of rural improvement, public funds have also been directed into health, recreational, cultural, and educational facilities intended ultimately to enhance the human resources invested in agriculture. ${ }^{12}$

The primary legislative means to furthering agricultural modernization in a great many countries has been the land reform law, in which 
there is great variety. A number of land reforms have been punitively directed and draconically enforced against larger landholders, sometimes under the banner of heightened efficiency, sometimes out of intentions to eliminate aliens and absentees, and sometimes as unabashed campaigns of class warfare in the countryside. In this latter regard, Stalin's drive against the kulaks is notorious. ${ }^{13}$ As noted earlier, there are few general lessons to be drawn from experience with land reform and its relation to agricultural modernization. As an agricultural policy, many governments, especially in Latin America, still continue to look at adjusting land tenure, however, as the final step toward rural improvement. The policy analyst's task is to determine what kinds of land reform best contribute to rural modernization and what kinds are least productive.

Border controls and foreign relations are also means that serve rural development ends. In some cases where conditions are propitious, governments find that integrating their agricultural sector or parts of it with the world economy supports internal development; in other instances, isolating agriculture has been a preferred strategy. Where cash crops for export are important sources of development capital, as with many coffee, cocoa, sugar, and cotton producing countries, export taxes and foreign policies aimed at stable markets and enhanced earnings are bound to development programs that rely on exchange earnings for financing, as in Ghana (see Bates, Chapter 9). On the other hand, where unreasonable foreign competition, in grains or processed food, for example, threatens bankruptcy even to efficient local farmers, tariff protection and consequent insulation from the world economy become ingredients of planning for rural development. Interestingly, almost every country that has experienced rural modernization passed through a high tariff period during initial and middle phases of development. Other ways in which foreign policy means serve rural modernization ends typically include relying on external markets for agricultural inputs, looking to more advanced countries, multinational firms, and international organizations for information and technology, and seeking development capital from abroad (as does Iran, see Chapter 6). Remarkable strides toward rural modernization in Taiwan and South Korea, and in Israel as well, can be attributed in considerable measure to American public and private development assistance. ${ }^{14}$ But then too a measure of early American agricultural growth also followed from overseas investment. ${ }^{15}$ Finally, while there is controversy about the efficacy of foreign food aid as a stimulant to rural development, some governments have managed to integrate aid into modernization 
programs in an imaginative way-in the form of "food-for-work" on rural infrastructure projects, or as "crop insurance" to encourage experiments with new technologies. ${ }^{16}$

Development in the countryside does not usually occur spontaneously. People generally do not change their modes of living and livelihood, even when desperate, until they are convinced that change will either bring rewards or avoid punishments. The task of executing policies aimed at change therefore involves governments in the search for appropriate administrative instruments. Styles of official promotion and enforcement during rural modernization range from gentle urging to brutal coercion, although, typically, incentives and enticements are preferred over sanctions. The Chinese government continues to rely rather heavily, though hardly exclusively, on symbols and propaganda-slogans, campaigns, wall posters, verbal exhortation, exemplary behavior, and the like-and the Indian government has also used such methods with some effect. ${ }^{17}$

Many governments direct their market interventions at providing incentives for innovation, for instance in cases where genetically superior seeds are publicly subsidized and fertilizers are distributed below cost to encourage their adoption. Some governments, such as the Japanese, have effectively mobilized rural elites and farmers' organizations to lead modernization drives. Still others, like the Chinese nationalist government, have linked their agricultural extension services with their gendarmerie to monitor compliance with official policies (see Chapter 5 on Taiwan), and elsewhere, in a few cases, development goals have been enforced by imprisoning or executing recalcitrant peasants.

\section{Origins and Allocation of Resources for Development}

No policy can help attain goals without resources, and experience in many countries reveals that rural modernization requires substantial investments of time, energy, intellect, and money. The origins of resources for agricultural development, however, differ considerably over time and space. In North America and in some European countries and their colonies, investing in rural development was, by and large, a private-sector undertaking. Opportunities were signalled by expectations of high return; initiative followed from individual entrepreneurship; capital came from private institutions and was granted to the state from a stock of uninhabited or expropriated property. Early public investment in these cases was limited to supporting research and sometimes funding the development of infrastructure (although in 
North America even infrastructure was privately financed and engineered until well into the twentieth century). The official policy, if it can be called that, was to promote the uninhibited operations of private capital markets by interfering as minimally as possible.

Elsewhere, of course, the origins of resources for development were to be found in the public sector-planning and administration became surrogates for entrepreneurship; ministries of development or rural reform and marketing boards replaced private financial institutions and commodity exchange; and fiscal receipts served the function of private savings. Policy under these conditions embodies an orchestration of fiscal means, revenue needs, and anticipated costs of development strategies. In instances where public revenues turn out either inadequate or unreliable, governments may choose to finance development through domestic inflation, as Brazil did during the 1960s, or through foreign borrowing, as Peru, Sudan, and other countries in Asia and Africa have done in recent years. ${ }^{18}$ Ultimately, there is no "better" or "poorer" way to finance rural modernization, since much depends on the location of resources, the relative allurement of alternative investment opportunities, the strength and integrity of bureaucratic institutions, and the level of entrepreneurship in different countries at different times. Needless to say, much also depends on the magnitude of the development task and the rapidity with which it must be accomplished.

There are, however, "better" and "poorer" investment strategies for rural modernization, or at least there are some lessons to be learned from experience. There is, of course, the standard economic rule of thumb that advises investment to compensate for scarce factors-by rendering them more plentiful or more productive. Investing in mechanization, for example, compensates for scarce labor, investing in fertilizer raises the productivity of scarce land, investing in irrigation makes more efficient use of scarce water, sinking new wells makes water more abundant, and so on. Repeating this scarcity dictum would be a trivial exercise were it not for the fact that it is so often, and disappointingly, overlooked in many countries' agricultural development programs, especially in those, like Pakistan's, where mechanization in agriculture becomes a goal in itself, pursued without regard to land, labor, and capital ratios (see Chapter 8). The connection between factor scarcities and investment strategies therefore bears monitoring. If capitalintensive technology is subsidized at the same time that rural unemployment is growing, for instance, one may immediately suspect that advantaged groups, such as large landholders or urban elites, have substantial influence over the policy. 
The sequence of investment targets is also important. Early investments to improve the quality of human resources tend, for example, to correlate rather closely with later accomplishments in agricultural production and productivity. Government drives to promote literacy in the countryside before promoting more elaborate programs of technological change unquestionably contributed to progress in rural modernization in the United States, Europe, Japan, Taiwan, and China. ${ }^{19}$ The productive impact was particularly noteworthy in China, where, since the revolution of 1949, rural education has been combined with measures to improve the health and nutrition of the rural population. Similarly, early investment in transport and communications also appears to be directly linked to making rapid strides toward modernization. Overcoming bottlenecks in marketing and distribution by providing roads, railroads, and waterways, and integrating farmers into information networks via media and extension services, contribute significantly to the shift from subsistence agriculture to the specialization in production and new rural-urban divisions of labor which necessarily accompany modernization. Furthermore, early investments in agronomic research have tended to speed rural modernization and to bring benefits which far outweigh the cost of research establishments. European accomplishments are a testament to this, the Dutch, Danish, and British especially. But this has also been the case for Japan, Canada, and the United States, as Hadwiger, Talbot, and Aall point out in Chapters 2 and 3. The point that fundamental investments to improve the environment for agriculture should come before specific drives to change technology, though obvious, is frequently overlooked in practice, as several of this volume's essays demonstrate (e.g., the chapters by Schulz and Bates).

\section{Institutions for Rural Modernization}

As the countryside changes, farms and other producing units are altered in structure and function, markets are established or superseded, schools are founded, financial and credit facilities such as banks and cooperatives emerge, research and extension services are introduced, and farmers organize for economic and political action. A good deal has already been said about created and transformed infrastructure during rural modernization. What needs to be underlined is that promoting or suppressing various rural institutions and political movements is inevitably a component of official development policies. Moreover, building institutions that are appropriate to conditions in the countryside and complementary both to farmers' needs and govern- 
mental objectives is a challenging problem for policymakers. Contrariwise, encouraging inappropriate or ill-designed institutions, such as many cooperatives in Africa in the 1960s proved to be, can be a formula for failure.

Agricultural production units assume considerable variety, and, although different kinds usually coexist in any country, governments tend to emphasize particular ones as vehicles for development. Compare, for example, American official encouragement of the "family farm" with Danish emphasis on the cooperative, Soviet promotion of the kolkholz or collective farm, Tanzanian ujamaa villages, and the elaborately tiered Chinese system of teams, brigades, and communes. Which institutions are deemed ideologically superior depends ultimately on one's leanings; which ones are appropriate vehicles for rapidly raising production and productivity depends on prevailing socio-cultural milieus and peculiar problems of resources and agronomy in given countries. Therefore, connections between kinds of producing units and kinds of development outcomes under varying contexts warrant monitoring. Much the same can be said for marketing institutions and credit facilities. Which contribute best to rural modernization? Traditional money lenders who charge usurious rates of interest but lend to even the poorest applicant? Modern banks that charge reasonable interest but lend to only some applicants? Or government ministries that charge nominal interest but lend for certain projects or to certain people only?

Farmers' organizations and rural political associations deserve special attention in the analysis of rural modernization. Experience in Japan and Taiwan has shown that farmers' associations can be exploited by governments as vehicles of modernization and carriers of technological change-in effect, as extensions of extension services. Conversely, as in the United States, an elite "subsystem" can capture the benefits of government largely for itself. With appropriately recruited and rewarded leadership, organizations can serve as instruments of surveillance and even agents to enforce compliance with official policies whether they favor current rural elites (as in Pakistan) or seek to displace them (as has occurred in Taiwan). More generally, farmers' organizations have been channels through which information about the impacts of policies has flowed back to governments. As such they have proven essential to monitoring the effects of policy and crucial to the governmental capacity for timely adjustment. What is important for policy analysis, and what some of the following essays discuss is the extent to which governments have used or abused various farm organizations during rural development. Another question that is 
examined is what has resulted from their various attitudes and actions toward these organizations?

Finally, there are the institutions of technological innovations per $s e$-research and extension services. It is fair to say that in every successful case of rural modernization that we are aware of government has been instrumental in fusing science and technology with agriculture. Even in the United States, where much of the technological development was in the private sector, federal and state investment in university research in agronomy and forestry was notable in the nineteenth century, when the land grant college network was established. The European tradition of public subsidization of agricultural research is, of course, much older, especially in plant and animal genetics in Russia, Prussia, and England. On the other hand, underemphasis on technology and low funding for agricultural research proved costly to both Indian and Chinese rural modernization during the 1950s, and insufficient research and technological innovation currently poses a major obstacle to rural development in Africa.

Extension services are equally important. If a government does not have the capacity to reach farmers directly, broad-gauged policies of rural development cannot be executed effectively or monitored adequately. Creating, maintaining, and effectively using an agricultural extension service appears to be an ingredient of every successful case of rural modernization. The absence or ineffectiveness of such structures contributed to the failure of the land reform efforts in Bolivia in the 1950s (where newly "landed" peasants could not be shown how to use their resources) and to lagging production growth in some Indian states where agricultural extension agents preferred not to go into the countryside to meet farmers.

Encompassing all these institutional developments and a phenomenon inextricably linked to agricultural and rural modernization is the expansion of government. All the kinds of changes in agriculture that we have reviewed have reflected or spurred the expansion of state power in the countryside. There are two reasons for this. First, for traditional agricultural patterns to be supplanted by new rural institutions and practices-such as changed land-tenure systems or ownership distribution, increased credit, and new planting and marketing techniques-new (usually national) bases for authority and the settlement of conflicts are required and facilitated. That is, rural change can be the forerunner as well as the product of new government, as has happened in China. Second, new practices require expanded services-new types of production inputs, regulation of diseases, rules to insure that wider markets operate securely, and an expansion of physical 
infrastructure, education, and extension work. The concern of comparative policy analysis is to determine which of these have worked successfully within varying contexts.

\section{Policy Analysis and Comparative Case Studies}

If we could know which combinations of official goals, degrees of intervention, political and administrative means, sources and uses of resources, and institutional emphases would yield successful rural modernization under various conditions, our capacity to prescribe would be a good deal more advanced than it is at present. Unfortunately, we have not yet accumulated the systematic knowledge required to guide governments toward courses of action that are simultaneously economically efficient, politically practicable, socioculturally appropriate, and agriculturally productive. That we lack this knowledge is a major justification for this volume and a recurrent theme of its chapters.

Implicitly or explicitly there are at least six issues on the policy agendas of countries undergoing rural modernization-land ownership, degree of foreign control, scale biases of technology, rural versus urban biases, food versus nonfood production, and the instrumental versus the consummatory role of the rural populace in modernization. Some or all of the policy components identified earlier affect the practical resolution of each of these issues. Moreover, these issues are not independent of each other. Their resolution leads to the particular policy configuration of a given country. Of course, this "configuration" may or may not be stable over time and may or may not be conducive to growth in agricultural productivity. The case studies of six countries that follow, along with the three region-oriented analyses (Chapters 3, 9, and 10), do not systematically review the manner in which each of these issues was resolved nor the apparent effects of each. Each chapter's analysis does, however, examine some or most of these issues. ${ }^{20}$

\section{Land Ownership}

Keith Griffin, among others, has argued that redistribution of land ownership would be the most effective means of reducing rural inequality and poverty and would increase production and total income in most contexts. ${ }^{21}$ He notes that small farmers tend to use land more completely and with higher yields and value added per hectare, as evidenced by studies in Bangladesh, Malaysia, Sri Lanka, Indonesia, Thailand, Pakistan, India, and the Philippines. ${ }^{22}$ Yet land reforms have frequently been inconsequential or outright failures, since much more than simply redistribution is required, including considerable political 
"costs." Two questions really come up with respect to land: What form shall "ownership" take (i.e., shall individual communities or the government be given title), and how equitable should distribution be? Land ownership, as we see in the Iranian, Russian, and Chinese cases (Chapters 4 and 7) can be used most importantly for political ends, either to reinforce traditional rule or to revolutionize a society. When development goals (e.g., production growth with or without equity) are uppermost, economic rather than political calculations are presumably determinative. In any event, policy elements such as goals, resources, and institutions will all be affected by the way a regime settles the question of land ownership.

\section{External Control}

As we noted in several cases, notably Pakistan, Iran, Korea, and Taiwan, there has been a heavy reliance on external inputs and a tolerance of foreign control in agricultural development. Interestingly, both China and Taiwan have achieved considerable equity among their rural populace while following or being subject to quite opposite degrees of foreign control, especially since 1949. Furthermore, Cuba, which sought to reduce foreign control after 1960, has met with some difficulties as sugar production has declined and general dependence on the Soviet Union has replaced that previously enjoyed by the United States. The effects of foreign involvement and influence, therefore, generally depend on the context; for example, they can be said to have been favorable in Taiwan, mixed in Iran and Africa, and detrimental in Pakistan and China.

\section{Technology}

Different technologies carry with them different "biases"; in particular, most capital-intensive technologies, such as tractors, are not scale-neutral but rather give advantage to the larger, wealthier farmers (as the Pakistan case makes clear; see Chapter 8). The most obvious "non-transferable" element in the American experience, according to Hadwiger and Talbot (Chaper 2), is our specific technology. Technology "choice" has a major effect on the policy options available to developing countries. Different choices produced different options for the earlier developers of Europe, according to Aall (Chapter 3). More important than the technological inputs that capital investment can buy may be the forms of the technology: Which kinds of farms and farmers does it advantage? Is it scale-neutral or does it favor extensive or intensive cultivation? Even though the effects of the "green revolution" have been more scale-neutral than many expected, continuing technological 
innovation of the same kind in less agronomically favorable areas may well lead to wide-spread impoverishment and a more volatile political role for rural areas. ${ }^{23}$ If policy decisions resolve the issue of kind of technology in favor of one with a large farm bias (usually through subsidies and provision of services for farm commodities), then the "choice" of equitable land distribution would work at cross-purposes to the goal of increased production. Hence, the effect of technology may be as important for equity as for production if it favors large landowners for certain regions to the absolute disadvantage of others.

\section{Rural Versus Urban}

A fourth issue for policy resolution is the question of whether to favor rural or urban populaces. ${ }^{24}$ As we noted earlier, all development involves intersectoral stimulation-industry in towns and agriculture in the countryside advance together, as Aall notes pointedly for England. However, production in one sector may be supported by the other through direct intersectoral transfers as well, usually through government taxes. Classically, the city has advanced at the expense of the rural population, whether through cheap-food policies, confiscation of export earnings, or other causes. This pattern, whether found in the United States, the Soviet Union, or Ghana, is no longer likely to yield the same growth effects. And in the wake of such intersectoral transfers, the basis for rural tensions, given the diffusion of expectations, is now much greater. Bates's discussion of the discontent among Ghanaian cocoa growers (Chapter 9) illustrates this point.

\section{Food Versus Nonfood}

A fifth issue is whether food self-sufficiency should be encouraged through extra-market incentives. Iran and Korea, with their declining food production compared to demand, have chosen to subsidize consumer prices, though not totally at producers' expense. The government has instead paid a subsidy to maintain a differential between higher farm and lower urban retail prices. Other related policies do harm farmers. For instance, when higher earning export crops or cheaper food imports (e.g., food aid) create incentives to move away from food production, this shift will also affect the urban-rural terms of trade because cheaper food prices generally favor the urban population. Policies in Iran, Pakistan, and elsewhere favoring export crops and/or imported extensive-type technologies for food production are surprising in the wake of the global food shortages of 1973-74 and the projections of substantial and growing food deficits in less developed countries as a whole-expected to be 185 million tons by 1990 , up from 
21 million tons in $1975 .{ }^{25}$ Nicholson and Esseks (Chapter 10) discuss a number of the problems food shortages pose for policy makers in developing countries.

\section{Role of the Rural Populace}

A final issue is the political role played by the rural populace in policy making: Modernization through revolution has been advanced as rural "classes" aided revolutionary efforts in China, Russia, Cuba, and elsewhere (see Bernstein, Chapter 4). ${ }^{26}$ At the opposite extreme, the countryside may be viewed as politically impotent, serving principally as a supplier of capital through "profits" captured by the government to support urban industrialization. In the Soviet Union, the Russians may have played both these roles from 1917 through 1937. The goals of policies, of course, are important in reflecting or establishing these alternative roles in modernization. At one extreme the well-being of the rural populace may be regarded as an end in itself and, hence, growth in their consumption becomes a critical yardstick for evaluating policy. At the other extreme, rural people are seen as an instrument of production whose immiscibility is irrelevant to policy evolution, except as it may have a negative effect on production or political stability.

Although some consultants believe that they can knowledgeably and confidently offer advice on these issues, we recommend caution. There is at present a respected body of theoretical knowledge concerned with the economics of development and an equally impressive body in the fields of theoretical and applied agronomy and the cognate sciences. Drawing on these helps achieve a better and more systematic understanding of rural modernization but can hardly complete the intellectual task, since, as noted earlier, they fail to take into account the economic, social, and cultural factors that shape politics and affect policy implementation. In contrast to theoretical scientific analyses, there is also a wealth of practical experience with agricultural modernization-scores of cases, historical and contemporary, libraries of description, documentation, anecdotal insights, and case-study materials that can be mined by scholars in the search for a more complete and systematic understanding of relationships between public policies and rural transformation. What these case analyses can show is that under particular conditions certain combinations of policy components produced particular results-some good, some bad. Multiplying cases and reconfirming relationships increases the generality of the findings, and, ultimately, such comparative research and inductive logic can yield systematic knowledge. This book's collection of case studies of rural modernization is a preliminary and very small step in the direction of such knowledge. We 
certainly do not recommend that Third World governments delay efforts at agricultural development while scholars accumulate more complete knowledge about the process. There is no time for this. We do suggest that governmental efforts will become more successful as our understanding becomes more complete and contextually relevant. There is an urgency, then, in the task that we have proposed to our colleagues and begun work on in the chapters of this volume.

\section{Notes}

1. Bruce F. Johnston and Peter Kilby, Agriculture and Structural Transformation (New York: Oxford University Press, 1975); Yujiro Hayami and Vernon W. Ruttan, Agricultural Development: An International Perspective (Baltimore and London: The Johns Hopkins Press, 1971); Theodore W. Schultz, Transforming Traditional Agriculture (New Haven: Yale University Press, 1964); Laurence Hewes, Rural Development: World Frontiers (Ames, Iowa: The Iowa State University Press, 1974); Melvin G. Blasee, ed., Institutions in Agricultural Development (Ames, Iowa: The Iowa State University Press, 1971); Keith Griffin, The Political Economy of Agrarian Change (Cambridge, Mass.: Harvard University Press, 1974).

2. Johnston and Kilby, Agriculture and Structural Transformation, pp. 3475 .

3. Daniel Lerner, The Passing of Traditional Society (New York: The Free Press, 1958), pp. 19-75.

4. Cf. John T. Schlebecker, Whereby We Thrive: A History of American Farming, 1607-1972 (Ames, Iowa: The Iowa State University Press, 1975); Murray R. Benedict, Farm Policies of the United States: A Study of Their Origins and Development (New York: Twentieth Century Fund, 1956); Gilbert C. Fite, American Agriculture and Farm Policy Since 1900 (Washington, D.C.: The American Historical Association, Waverly Press, 1964); Yujiro Hayami, A Century of Agricultural Growth in Japan (Minneapolis and Tokyo: University of Minnesota Press and University of Tokyo Press, 1975).

5. John W. Mellor, The Economics of Agricultural Development (Ithaca, N.Y.: Cornell University Press, 1966), pp. 223-244; John W. Mellor et al., Developing Rural India (Ithaca, N.Y.: Cornell University Press, 1968), pp. 3193; Lazar Volin, A Century of Russian Agriculture (Cambridge, Mass.: Harvard University Press, 1970), pp. 203-274.

6. Schlebecker, Whereby We Thrive; Benedict Stavis, People's Communes and Rural Development in China (Ithaca: Cornell University Rural Development Committee, RLG no. 3, 1975); Benedict Stavis, Making Green Revolution: The Politics of Agricultural Development in China (Ithaca: Cornell University Rural Development Committee, 1974); Elizabeth and Graham Johnson, Walking on Two Legs: Rural Development in South China (Ottawa: International Development Research Center, 1976); Sterling Wortman, "Agriculture in China," Scientific American 232, no. 6 (June 1975):13-21; Edward Boorstein, 
The Economic Transformation of Cuba (New York and London: Monthly Review Press, 1968); Teresa Castro, Cuba and Castro (New York: Random House, 1961).

7. G. Edward Schuh, The Agricultural Development of Brazil (New York: Praeger, 1970); William H. Nicholls, "The Transformation of Agriculture in a Semi-Industrialized Country: The Case of Brazil,"' in Erik Thorbecke, ed., The Role of Agriculture in Development (New York; Columbia University Press, 1968), pp. 311-378; Gordon W. Smith, "Brazilian Agricultural Policy, 1950-1967," in Howard S. Ellis, ed., The Economy of Brazil (Berkeley, Calif.: University of California Press, 1969), pp. 213-265; Tomaz Wybraniec, "Peasant Farming in Poland: Performance and Prospects,"' Paper presented at Conference on Soviet and Peasant Affairs, August 1967. On socialist and communist experiences more generally, see W. A. Douglas Jackson, ed., Agrarian Policies and Problems in Communist and Non-Communist Countries (Seattle and London: University of Washington Press, 1971).

8. Cf. Chapter 1, Stuart Thomas, "Authoritarian Politics: The Case of the Chilean Agrarian Reform" (Ph.D. diss., Columbia University, Department of Political Science, 1978); Pamela Aall McPherson, "Politics and Agriculture in Nineteenth Century Ireland" (New York: Columbia University, Institute on Western Europe, 1977); Frances M. Foland, "Agrarian Reform in Latin America," Foreign Affairs 48, no. 1 (October 1969):97-112.

9. Schlebecker, Whereby We Thrive, pp. 71-86; Volin, Century of Russian Agriculture, pp. 235-274.

10. Hayami and Ruttan, Agricultural Development, pp. 111-168; Johnston and Kilby, Agriculture and Structural Transformation, pp. 182-240; Hayami, Century of Agricultural Growth in Japan, pp. 44-86.

11. Gordon W. Smith, "Brazilian Agricultural Policy," p. 215.

12. Stavis, People's Communes, pp. 136-165; Boorstein, Economic Transformation of Cuba, passim; Carmelo Mesa-Lago, Cuba in the 1970's (Albuquerque, N.M.: University of New Mexico Press, 1978), pp. 30-61.

13. Volin, Century of Russian Agriculture, pp. 203-235.

14. Cf. Chapters 5 and 6 in this volume.

15. Gilbert C. Fite and Jim E. Reese, An Economic History of the United States (Boston: Houghton Mifflin, 1965), pp. 135, 163-185, 380-405.

16. U. K. Srivastava et al., Food Aid and International Economic Growth (Ames, Iowa: The Iowa State University Press, 1975), pp. 37-64, 113-123.

17. Stavis, Making Green Revolution, pp. 22-54; Mellor et al., Developing Rural India, pp. 33-55.

18. G. Edward Schuh, Agricultural Development of Brazil, pp. 4-17. See also G. Edward Schuh, "Effects of Some General Economic Development Policies on Agricultural Development," American Journal of Agricultural Economics 50, no. 5 (December 1968):1283-1293.

19. Note especially the Japanese case as described by Hayami, Century of Agricultural Growth in Japan, pp. 107ff.

20. If our introduction had been prepared before the chapters were completed, more systematic treatment by the authors of these issues would have occurred. 
21. Keith Griffin, The Political Economy of Agrarian Change (Cambridge: Harvard University Press, 1974); and Keith Griffin, Land Concentration and Rural Poverty (New York: Holmes and Meier, 1976).

22. Azizur Rehman Khan, The Economy of Bangladesh (London: Macmillan, 1972), pp. 131-136; Keith Griffin, Political Economy of Agrarian Change, pp. 39-45; and R. Albert Berry and William R. Cline, "Farm Size, Factor Productivity, and Technical Change in Developing Countries," manuscript draft, 1976.

23. Vernon Ruttan, for instance, argues that the initial effects of the green revolution were to increase productivity rather generally in the areas where it was adopted early, at least after four to five years, but that new productivity gains may come more slowly and with far less equity, thus spurring revolutionary impulses in the countryside. In Vernon W. Ruttan, "Induced Institutional Innovation and the Green Revolution," Philippine Economic Journal (1977).

24. For a discussion of "urban biases" endemic in many countries' policies, see Michael Lipton, Why the Poor Stay Poor (Cambridge: Harvard University Press, 1976).

25. See Food Needs of Developing Countries: Projections of Production and Consumption to 1990 (Washington: International Food Policy Research Institute, 1977), pp. 44-53.

26. This point is well made by Scott, who notes that peasants rather than proletariat have been more important in twentieth century revolutions, a rather un-Marxist argument. See James Scott, "Hegemony and the Peasantry," Politics and Society 7 , no. 3 (1977):267-295. 